\title{
Analysis of chromium(IV) levels in residents' well water around the Citarum River, Indonesia
}

\author{
Farhan Baehaki ${ }^{1}$, Yasser Wahyudin², Ryzal Perdana ${ }^{3}$, Arlisya Siti Nurfajar ${ }^{4}$, Zidni \\ Irpan Syaripudin 5
}

\author{
1,4,5 Medical Laboratory Technology, Institut Kesehatan Rajawali, Indonesia \\ ${ }^{2}$ Faculty of Engineering, Lyon University, France \\ ${ }^{3}$ Faculty of Teacher Training and Education, University of Lampung, Indonesia
}

\begin{abstract}
Wells as a source of water that is commonly used by people in Indonesia are very dependent on the conditions of the surrounding environment. The presence of environmental pollution by waste will be very dangerous, especially if the waste contains heavy metals such as $\mathrm{Cr}(\mathrm{VI})$. The highly soluble nature of $\mathrm{Cr}(\mathrm{VI})$ allows the process of infiltration from the river into the well water. This study aims to analyze the content of $\mathrm{Cr}(\mathrm{VI})$ in the well water of residents around the Citarum River. Samples were taken from two areas that have the criteria for the level of pollution and the environment which is dense with industrial activity, with a total of ten wells spread over the area. The concentration measurement was carried out using an atomic absorption spectrophotometer at a wavelength of $357.9 \mathrm{~nm}$. The results showed that the levels of $\mathrm{Cr}(\mathrm{VI})$ ion at Location 1 were in the range of $0.014-0.022 \mathrm{ppm}$ so that it could still be used for daily activities because it was below the threshold value. At Location 2, there are six wells whose water is still suitable for use because the value of the $\mathrm{Cr}(\mathrm{VI})$ ion content is still below the threshold value. Meanwhile, the water in the other four wells contains a $\mathrm{Cr}(\mathrm{VI})$ ion level that exceeds the threshold value, so it can be said that it is not suitable for daily use.
\end{abstract}

\section{KEYWORDS}

Waste, heavy metals, chromium(IV), well water, Citarum River

\section{ARTICLE INFO}

Received: 22 June 2021

Accepted: 28 June 2021

Published: 29 June 2021

\section{INTRODUCTION}

Water is a substance that is very important for life so that its quality and quantity need to be maintained properly. In Indonesia, water sources generally come from groundwater in the form of well water (Tumanggor, Dharma and Marsaulina, 2012). The quality of this water source is strongly influenced by conditions in the surrounding environment. Of course this needs to be a concern for people who live in areas whose environmental conditions have been polluted, such as in the area around the Citarum River, West Java 
Province, Indonesia.

Citarum River is one of the rivers in Indonesia whose condition has been severely polluted. Pollution is generally caused by waste generated by household and industrial activities. Industrial activity is something that needs more attention, because the amount of waste generated is very large. The increase in the number of industries will be directly proportional to the amount of waste produced (Baehaki et al., 2020). Especially with the facts that it was found that not all industries did waste treatment before being discharged into the Citarum River, especially in the lower and middle industries. This is related to the high cost of processing waste so that the industry prefers to directly dispose of the waste without treatment (Baehaki et al., 2020; Olukanni, Agunwamba, and Ugwu, 2014; Kocasoy and Guvener, 2009; Acar and Malkoc, 2004). According to CNBC Indonesia (2018), the largest type of waste that pollutes the Citarum River Basin is industrial liquid waste with a total of 349,000 per tonne per day. The waste comes from 1,900 factories along the Citarum watershed, and unfortunately only $10 \%$ of these factories have adequate Wastewater Treatment Plants.

Many different types of waste are dumped into the Citarum River. However, the waste of concern is heavy metal waste, such as chromium (Malik, Surakusumah, and Surtikanti, 2016). This is because heavy metals are waste included in the category of Toxic and Hazardous Materials (Lichtfouse and Schwarzbauer, 2012; Irhamni, 2017). Chromium is usually used in the textile industry, especially for the dyeing process. The large number of textile industries around the Citarum River Basin causes a high risk of exposure to chromium metal into the river. There are two forms of chromium ions produced from the textile industry activities, namely $\mathrm{Cr}(\mathrm{III})$ and $\mathrm{Cr}(\mathrm{VI})$ ions. However, between the two ionic forms, $\mathrm{Cr}(\mathrm{VI})$ is theform that needs to be focused on because it is toxic. Chromium in the form of $\mathrm{Cr}(\mathrm{VI})$ ion has a very high solubility. This characteristic is a concern for the environment, especially in the residents' wells that serve to function as water sources. Its high solubility allows $\operatorname{Cr}(\mathrm{VI})$ to also seep into the well so it is at risk for consumption by residents (Nuraini, Endrawati, and Maulana, 2017) resulting in negative impacts on body health (Abdi and Kazemi, 2015; Rodríguez et al 2018). Therefore, this study was carried out to further analyze the content of $\mathrm{Cr}(\mathrm{VI})$ ions in the residents' well water.

\section{LITERATURE REVIEW}

\section{Chromium waste}

Chromium is a type of heavy metal waste and is included in the category of Hazardous and Toxic Materials (B3) (Lichtfouse and Schwarzbauer, 2012; Irhamni, 2017; Loukidou, Zouboulis, Karapantsios, and Matis, 2004; Kiziloz, 2019). Chromium waste comes from various industrial activities such as the chrome plating industry, textile factories, paint factories, leather tanning, ink factories, photography, steel and other metal alloy production, and oil refining (Adhani and Husaini, 2017; Acar and Malkoc, 2003). However, of these various types of industries, the textile industry is the largest contributor to chromium waste (Baehaki et al., 2020). 


\section{Characteristics and Toxicity of $\mathrm{Cr}(\mathrm{VI})$}

Chromium has different properties according to the level of ionity of the compound. $\mathrm{The} \mathrm{Cr}(\mathrm{II})$ ion is acidic, the $\mathrm{Cr}(\mathrm{III})$ ion is amphoteric, and the $\mathrm{Cr}(\mathrm{VI})$ ion is acidic (Palar, 2012). However, the $\mathrm{Cr}(\mathrm{III})$ and $\mathrm{Cr}(\mathrm{VI})$ ion forms are the most stable. Reduction of $\mathrm{Cr}(\mathrm{VI})$ to $\mathrm{Cr}(\mathrm{III})$ can take place if the water is acidic, whereas in alkaline solution, $\mathrm{Cr}$ (III) ions will precipitate (Palar, 2012). The $\mathrm{Cr}(\mathrm{VI})$ ion is the most toxic form of chromium metal because it has a high affinity for red blood cells when it enters the body (Hua et al., 2009; Palar, 2012; Nagaraj et al., 2009). Chromium in the form of $\mathrm{Cr}(\mathrm{VI})$ is very easily soluble in water, making it possible to enter the residents' clean water sources and be consumed (Palar, 2012; Baehaki et al., 2020). Toxic effects that can be caused by exposure to these ions are conjunctivitis, gastrointestinal liver necrosis, bleeding, renal tubular necrosis, kidney damage, allergic reactions, sneezing, loss of breath, eyes burning, shortness of breath, tooth discoloration, headache, coughing, pulmonary congestion. , corneal damage until blindness, ulcers, infection of the respiratory tract, and cancer (Palar, 2012; Adhani and Husaini, 2017; Baehaki et al., 2020; Effendi et al., 2012). These ions can react with various biological elements in the body so that it will disrupt the body's metabolic system (Sharov, Plotnikova, Evseev, Rykova, 2019). This is because the $\mathrm{Cr}(\mathrm{VI})$ ion will act as an inhibitor and inhibit the performance of the benzopyrene hydroxylase enzyme (Palar, 2012). Of course this will result in uncontrolled cell growth (cancer).

\section{METHODS}

The research adopted a descriptive method which aimed to find out the levels of $\mathrm{Cr}(\mathrm{VI})$ contained in the well water of residents around the Citarum river. The results of these levels were compared with the threshold value of $\operatorname{Cr}(\mathrm{VI})$ levels in the water. The research was conducted at the Applied Chemistry and Toxicology Laboratory, Institut Kesehatan Rajawali and the Central Laboratory, Padjadjaran University.

\section{Sample preparation}

Well water samples were taken at two points, namely in Cilampeni Village (Point 1) and Pangauban Village (Point 2), both were located in Katapang District, Bandung Regency, West Java, Indonesia. The selection of this area was based on the high activity of the textile industry, the high level of pollution, and the housing conditions of residents on the Citarum River banks. At each point ten samples of well water were taken from ten different wells. The distance of the wells wasconsidered with the following division:

1) four samples were taken from four wells ata distance of 10-30 meters from the river body;

2) three samples were taken from three wells at a distance of 30-60 meters from the river body; and

3) three samples were taken from wells of about 60-100 meters from the river body.

A total of $100 \mathrm{ml}$ of water was taken from each well which was then put into a container. Furthermore, the sample wasadded with nitric acid solution to preserve and stabilize the $\operatorname{Cr}(\mathrm{VI})$ ion (Baehaki et al, 2020). 
Farhan Baehaki, Yasser Wahyudin, Ryzal Perdana, Arlisya Siti Nurfajar \& Zidni Irpan Syaripudin

\section{Instrument}

The instrument used in this research wasthe Atomic Absorption Spectrophotometer. The sample was measured at a wavelength of $357.9 \mathrm{~nm}$ (Indonesian National Standard 06-6989.17-2009).

\section{Preparation of $100 \mathrm{ppm} \mathrm{K}_{2} \mathrm{Cr}_{2} \mathrm{O}_{7}$ solution}

The stock solution was prepared by weighing as much as $100 \mathrm{mg}$ of $\mathrm{K}_{2} \mathrm{Cr}_{2} \mathrm{O}_{7}$. After weighing, $\mathrm{K}_{2} \mathrm{Cr}_{2} \mathrm{O}_{7}$ was dissolved using distilled water and put into a $1000 \mathrm{ml}$ volumetric flask. Furthermore, the distilled water wasadded up to the limit mark.

\section{Creating standard curves}

To make a standard curve, a series of standard solutions of $\mathrm{K}_{2} \mathrm{Cr}_{2} \mathrm{O}_{7}$ were first made with a concentration of $0.2 \mathrm{ppm} ; 0.4 \mathrm{ppm} ; 0.6 \mathrm{ppm} ; 0.8 \mathrm{ppm}$; and $1.0 \mathrm{ppm}$. This standard solution series was prepared through adilution process of $100 \mathrm{ppm}$ stock solution. Preparation of this solution wascarried out with the following calculations.

- Standard solution 0.2ppm

$100 \mathrm{ppm} \times V_{1}=0.2 \mathrm{ppm} \times 100 \mathrm{ml}$

$$
\begin{gathered}
V_{1}=\frac{0,2 \mathrm{ppm} \times 100 \mathrm{ml}}{100 \mathrm{ppm}} \\
V_{1}=0.2 \mathrm{ml}
\end{gathered}
$$

- Standard solution 0.4ppm

$100 \mathrm{ppm} \times V_{1}=0.2 \mathrm{ppm} \times 100 \mathrm{ml}$

$$
\begin{gathered}
V_{1}=\frac{0,4 \mathrm{ppm} \times 100 \mathrm{ml}}{100 \mathrm{ppm}} \\
V_{1}=0.4 \mathrm{ml}
\end{gathered}
$$

- Standard solution 0.6ppm

$100 \mathrm{ppm} \times V_{1}=0.2 \mathrm{ppm} \times 100 \mathrm{ml}$

$$
\begin{gathered}
V_{1}=\frac{0,6 \mathrm{ppm} \times 100 \mathrm{ml}}{100 \mathrm{ppm}} \\
V_{1}=0.6 \mathrm{ml}
\end{gathered}
$$

- $\quad$ Standard solution 0.8ppm

$$
\begin{gathered}
100 \mathrm{ppm} \times V_{1}=0,2 \mathrm{ppm} \times 100 \mathrm{ml} \\
V_{1}=\frac{0.8 \mathrm{ppm} \times 100 \mathrm{ml}}{100 \mathrm{ppm}} \\
V_{1}=0.8 \mathrm{ml}
\end{gathered}
$$

- Standard solution 1.0ppm 


$$
\begin{gathered}
V_{1}=\frac{1.0 \mathrm{ppm} \times 100 \mathrm{ml}}{100 \mathrm{ppm}} \\
V_{1}=1.0 \mathrm{ml}
\end{gathered}
$$

To each of these standard solutions was added a solution of nitric acid to stabilize the $\mathrm{Cr}(\mathrm{VI})$ ion. Absorbance measurements were carried out at a wavelength of $357.9 \mathrm{~nm}$. The curve is made by plotting the concentration value ( $X$ axis) and absorbance value ( $Y$ axis) so that the equation of the line was finally obtained.

\section{Measurement of the levels of $\mathrm{Cr}(\mathrm{VI})$ in the sample}

The measurement of $\mathrm{Cr}(\mathrm{VI})$ ion content in the well water samples was carried out using an atomic absorption spectrophotometer at a wavelength of $357.9 \mathrm{~nm}$. The calculation of the content wascarried out using the equation of the line obtained in the standard curve making.

\section{RESULTS}

\section{Standard curve}

The standard curve was made to obtain a straight line equation that can be used to calculate the concentration of $\mathrm{Cr}(\mathrm{VI})$ in the sample. This method is the standard method of measuring using an Atomic Absorption Spectrophotometer. Generally, the greater the concentration, the higher the absorbance value (see Table 1).

Table 1. Absorbance measurement results of $\mathrm{K}_{2} \mathrm{Cr}_{2} \mathrm{O}_{7}$ standard solution

\begin{tabular}{cc}
\hline Concentration (ppm) & Absorbance \\
\hline 0.0 & $-0,0007$ \\
0.2 & 0,0125 \\
0.4 & 0,0258 \\
0.6 & 0,0438 \\
0.8 & 0,0576 \\
1.0 & 0,0673 \\
\hline
\end{tabular}

The data in Table 1 is then plotted into the $x$-axis (concentration) and the $y$-axis (absorbance). The plot of these values can form a straight line with the equation $y=m x+c$ (See Figure 1).

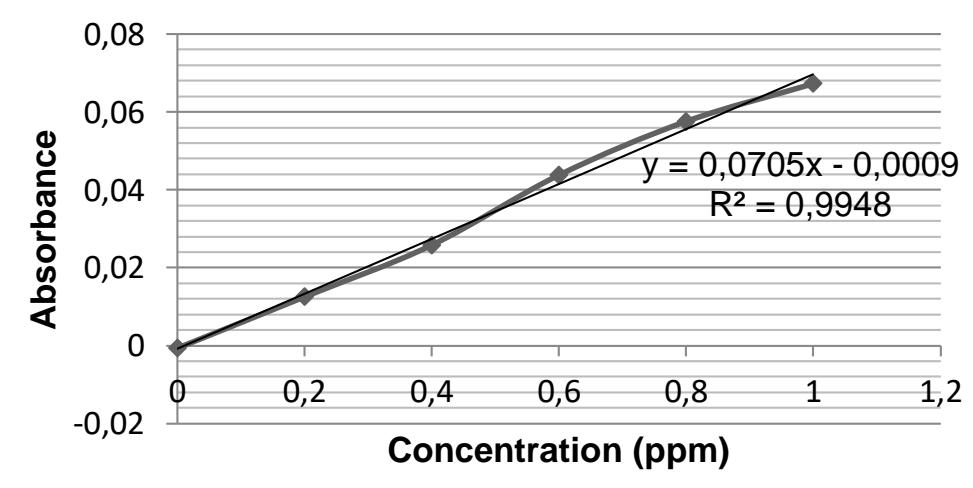

Figure 1. Standard curve of $\mathrm{K} 2 \mathrm{Cr} 2 \mathrm{O} 7$ standard solution 


\section{Concentration of $\mathrm{Cr}(\mathrm{VI})$ ions in well water}

The equation obtained based on the curve in Figure 1 is $y=0.0705 x-0.0009$. This equation is used to calculate the $\mathrm{Cr}(\mathrm{VI})$ ion content. The results of calculating the levels of $\mathrm{Cr}(\mathrm{VI})$ ions can be seen in Table 2 .

Table 2. Results of measurement of $\mathrm{Cr}(\mathrm{VI})$ ion levels in well water at Location 1 and Location 2

\begin{tabular}{|c|c|c|c|}
\hline Location & Sample code & Distance to River (meter) & Concentration(ppm) \\
\hline \multirow{10}{*}{$\begin{array}{l}\bar{c} \\
\text { 을 } \\
\overline{\mathbb{J}} \\
0\end{array}$} & 01 Loc 1 & $10-30$ & 0,022 \\
\hline & 02 Loc 1 & $10-30$ & 0,020 \\
\hline & 03 Loc 1 & $10-30$ & 0,019 \\
\hline & 04 Loc 1 & $10-30$ & 0,019 \\
\hline & 05 Loc 1 & $30-60$ & 0,018 \\
\hline & 06 Loc 1 & $30-60$ & 0,017 \\
\hline & 07 Loc 1 & $30-60$ & 0,017 \\
\hline & 08 Loc 1 & $60-100$ & 0,016 \\
\hline & 09 Loc 1 & $60-100$ & 0,015 \\
\hline & 10 Loc 1 & $60-100$ & 0,014 \\
\hline \multirow{10}{*}{$\begin{array}{l}\text { N } \\
\text { ᄃ } \\
\stackrel{0}{\mathbb{J}} \\
0 \\
\end{array}$} & 01 Loc 2 & $10-30$ & 0,101 \\
\hline & 02 Loc 2 & $10-30$ & 0,090 \\
\hline & 03 Loc 2 & $10-30$ & 0,023 \\
\hline & 04 Loc 2 & $10-30$ & 0,021 \\
\hline & 05 Loc 2 & $30-60$ & 0,022 \\
\hline & 06 Loc 2 & $30-60$ & 0,145 \\
\hline & 07 Loc 2 & $30-60$ & 0,008 \\
\hline & 08 Loc 2 & $60-100$ & $-0,027$ \\
\hline & 09 Loc 2 & $60-100$ & 0,176 \\
\hline & 10 Loc 2 & $60-100$ & $-0,024$ \\
\hline
\end{tabular}

In Location 1 data, all wells showed the presence of $\mathrm{Cr}(\mathrm{VI})$ ions with the lowest concentration of 0.014 ppm and the highest concentration of 0.022 ppm. Meanwhile at Location 2, the data did not show a good pattern. This may be influenced by several factors. There are 2 samples that show negative concentration values, so it can be said that the well does not contain any $\mathrm{Cr}(\mathrm{VI})$ ions. However, at Location 2 there is also a sample with the highest $\mathrm{Cr}(\mathrm{VI})$ ion content with a value of $0.176 \mathrm{ppm}$.

\section{DISCUSSION}

The first data obtained in this study is the standard curve. The equation obtained shows a good level of linearity with an $R^{2}$ value of 0.9948 , close to the ideal linearity value, namely $R^{2}=1$ (Hamita, 2004). This shows that the line equation can be used to determine the levels of $\mathrm{Cr}(\mathrm{VI})$ ions in the sample (Baehaki et al., 
2020).

The measurement of the $\mathrm{Cr}(\mathrm{VI})$ ion content showed a very interesting thing. In general, at Location 1, the $\mathrm{Cr}(\mathrm{VI})$ ion content data showed a relatively safe value, ranging from $0.014 \mathrm{ppm}-0.022 \mathrm{ppm}$. Meanwhile, the threshold value determined by the Government Regulation Number 82 of 2001 for levels of $\mathrm{Cr}(\mathrm{VI})$ ions in water is $0.05 \mathrm{ppm}$ (Kristianto, Wilujeng, and Wahyudiarto, 2017). This means that the condition of well water in Location 1 is still suitable for use in various daily activities.

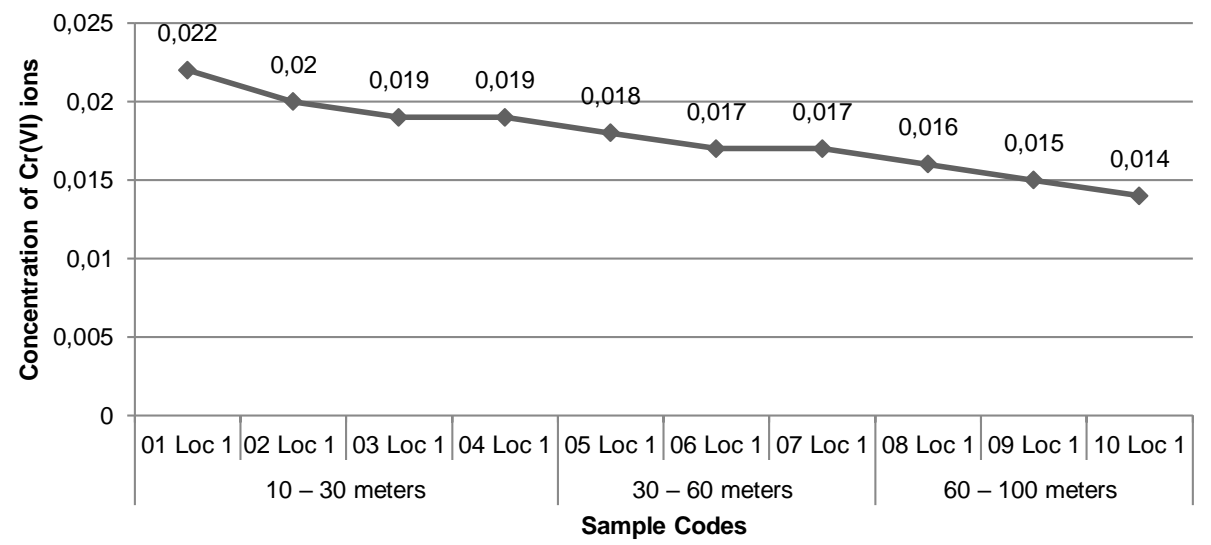

Figure 2. Graph of relationship between well distance and concentration of $\operatorname{Cr}(\mathrm{VI})$ ions at Location 1

The data in Table 2 regarding the levels of $\mathrm{Cr}(\mathrm{VI})$ ions at Location 1 show interesting things. There is a pattern formed from the relationship between well distance and $\mathrm{Cr}(\mathrm{VI})$ ion content. To facilitate analysis, the data in Table 2 is plotted into a graph as shown in Figure 2. In general, there is a tendency that the farther the distance from the well to the river body, the smaller the concentration of $\mathrm{Cr}(\mathrm{VI})$ ions. This indicates that the soil structure in the region can function well as a filter.

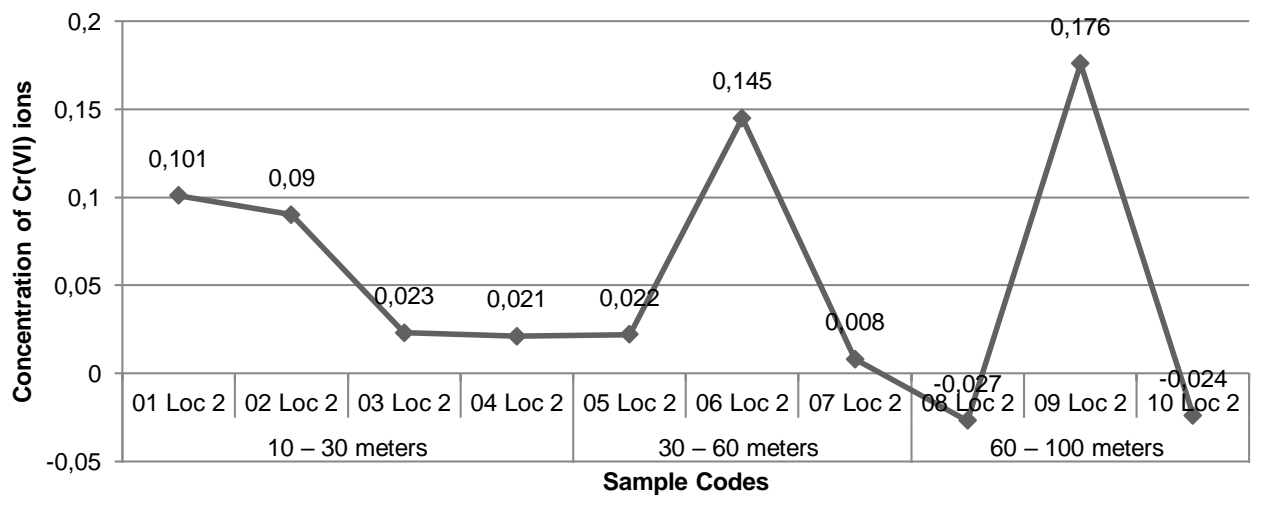

Figure 3. Graph of relationship between well distance and concentration of $\mathrm{Cr}(\mathrm{VI})$ ions at Location 2

At Location 2, there are very interesting data to be studied in more depth because there are variations in the concentration value of $\mathrm{Cr}(\mathrm{VI})$ ions. Of the ten wells that were used as sampling points, there were six wells that had $\mathrm{Cr}(\mathrm{VI})$ ion levels below $0.05 \mathrm{ppm}$. Thus, if referring to the Government Regulation Number 82 of 
Farhan Baehaki, Yasser Wahyudin, Ryzal Perdana, Arlisya Siti Nurfajar \& Zidni Irpan Syaripudin

2001, it can be said that the water in this well is suitable for use. However, there are four wells that have $\mathrm{Cr}(\mathrm{VI})$ ion levels above $0.05 \mathrm{ppm}$. Of course this needs to be the focusof further studies where there are efforts to reduce this value or prevent people from using the well water.

Broadly speaking, if we draw points on the sample 01 Loc 02 to 10 Loc 02 , there is a tendency for the $\mathrm{Cr}(\mathrm{VI})$ ion level to decrease as the well is farther away from the river. Therefore, it can be said that the soil in this location can serve to function as a filter as well. However, the sample data of 06 Loc 02 and 09 Loc 02 show deviations (see Figure 3). Even though the distance between the two wells is farther away, the $\operatorname{Cr}(\mathrm{VI})$ ion content should be less. The observation results indicate that the deviation phenomenon occurs because of the convection factory right near the well. The well is located close to the sewerage so that it is possible for the waste to infiltrate into the well because the $\mathrm{Cr}(\mathrm{VI})$ ion has a very high solubility (Palar, 2012; Baehaki et al., 2020). Of course, this needs to be a concern for the community because, if you look at the levels of $\operatorname{Cr}(\mathrm{VI})$ ions in the two wells, they are wells above the threshold value, which is $0.05 \mathrm{ppm}$. Health impacts can be caused if the water in this wellsareused continuously by the residents. The toxic effects that can be caused by exposure to these ions are conjunctivitis, gastrointestinal liver necrosis, bleeding, renal tubular necrosis, kidney damage, allergic reactions, sneezing, loss of breath, eyes burning, shortness of breath, tooth discoloration, headache, coughing, pulmonary congestion, corneal damage until blindness, ulcers, infection of the respiratory tract, and cancer (Palar, 2012; Adhani and Husaini, 2017; Baehaki et al., 2020; Effendi et al., 2012). However, to provide an appropriate picture, further research is needed regarding the analysis of chromium levels in the bodies of residents who use and consume the water from the wells.

\section{CONCLUSION}

Most of the well water in the area around the Citarum River Basin is still suitable for use when viewed from the content of $\mathrm{Cr}(\mathrm{VI})$ ions in it. However, there are several wells that need to be watched out for because the value of the $\mathrm{Cr}(\mathrm{VI})$ ion level is above the threshold value of $0.05 \mathrm{ppm}$. There is a relationship between the distance of the well to the river and the $\mathrm{Cr}(\mathrm{VI})$ ion level, where the farther the distance from the well to the river, the lower the $\mathrm{Cr}(\mathrm{VI})$ ion level. Therefore, it is advisable to build a well or source of clean water in a location far away from the river.

\section{ACKNOWLEDGEMENTS}

The authors would like to thank the Institut Kesehatan Rajawali, University of Lampung, Cilampeni Village Government, Central Laboratory at Padjadjaran University and Pangauban Village Government who provided us with assistance during this research.

\section{FUNDING}

This research received no specific grant from any funding agency in the public, commercial, or not-for-profit sectors. 


\section{REFERENCES}

Abdi, O. and Kazemi, M. (2015). A review study of biosorption of heavy metals and comparison between different biosorbents. J. Mater. Environ. Sci, 6(5), 1386-1399. https://www.jmaterenvironsci.com/ Document/vol6/vol6 N5/164-JMES-1454-2015-Abdi.pdf

Acar, F.N. And Malkoc, E. (2004). The removal of chromium(vi) from aqueous solutions by fagus orientalis I. Bioresource Technology, 94, 13-15.https://doi.org/10.1016/i.biortech.2003.10.032

Adhani R. dan Husaini (2017). Logam berat sekitar manusia. Banjarmasin: Lembaga Mangkurat University Press.

Baehaki, F., Rudibyani, R. B., Aeni, S. R.N., Perdana, R., and Aqmarina, S. N.(2020). Utilization of salacca zalaccaseeds as chromium(vi) adsorbents. Periodico Tche Quimica, 17(34), 381-389.

Effendi, F. et al. (2012). Occupational diseases due to heavy metal exposure. Jakarta: Directorate of Occupational Health and Sports, Ministry of Health of the Republic of Indonesia.

Hua, L., Chan, Y. C., Wu, Y. P., and Wu, B. Y. (2009). The determination of hexavalentchromium (Cr6+) in electronic and electrical components and products to complywith rohs regulations. Journal of Hazardous Materials, 163, 1360-1368. https://doi.org/10.1016/.j.jhazmat.2008.07.150

Irhamni, Pandia S., Purba E., dan Hasan W. (2017). Proceedings from Prosiding Seminar Nasional Pascasarjana (SNP) Unsyiah. Banda Aceh: Unsyiah. http://jurnal.unsyiah.ac.id/SNP-Unsyiah/article/ view/6858/5659

Kiziloz, B. (2019). Investigation of some hazardous agents and trace elements indrinking water of kocaeli region. Periodico Tche Quimica, 16(31), 381-389.

Kocasoy G. andGüvener, Z. (2009) Efficiency of compost in removal of heavy metals from the industrial wastewater. Environ Geol, 57, 291-296. https://doi.org/10.1007/s00254-008-1372-3

Kristianto S., Wilujeng S., dan Wahyudiarto D. (2017). Analisis logam berat kromium (cr) pada kali pelayaran sebagai bentuk upaya penanggulang pencemaran lingkungan di Wilayah Sidoarjo. Jurnal Biota, 3(2), 66-70.

Lichtfouse, E., Schwarzbauer, J., and D.Robert. (2012). Environmental chemistry for a sustainable world volume 1: Nanotechnology and health risk. New York: Springer.

Loukidou, M. X., Zouboulis, A.I., Karapantsios, T.D., and Matis, K.A. (2004). Equilibrium and kinetic modeling of chromium(vi) biosorption by aeromonas caviae. Colloids And Surfaces A: Physicochem. Eng. Aspects, 242, 93-104.https://doi.org/10.1016/i.colsurfa.2004.03.030

Malik R.A., Surakusumah W., Koosbandiah S.H. (2016). Potensi tanaman air sebagai fitoakumulator logam kromium dalam limbah cair tekstil. Jurnal Riset Teknologi Pencegahan Pencemaran Industri, 7(1). http://dx.doi.org/10.21771/jitppi.2016.v7.no1.p47-56

Nagaraj, P., Aradhana, N., Svivakumar, A., Shrestha, A. K., Gowda, A.K.(2009). Spectrophotometric method for the determination of $\mathrm{cr}(\mathrm{vi})$ in water samples. Environmental Monitoring and Assessment, 157, 575-582. https://doi.org/10.1007/s10661-008-0557-2

Notoatmojo, S.(2012). Metodologi Penelitian Kesehatan. Jakarta: Rineka Cipta.

Nuraini R.A.T., Endrawati H., dan Maulana I.R. (2017). Analisis kandungan logam berat kromium (cr)pada air, sedimen dan kerang hijau (perna virdis) di perairan Trimulyo Semarang. Tropical Marine Journal,20(1). https://doi.org/10.14710/jkt.v20i1.1104

Olukanni, D.O., Agunwamba, J.C., and Ugwu, E.I. (2014). Biosorption of heavy metals in industrial wastewater using microorganisms (pseudomonas aeruginosa). American Journal Of Scientific And Industrial Research, 5(2), 81 87.https://www.doi.org/10.5251/ajsir.2014.5.2.81.87

Palar, H. (2012). Pencemaran dan toksikologi logam berat $4^{\text {th }}$ Ed. Jakarta: Rineka Cipta.

Government Regulation of the Republic of Indonesia Number 82 of 2001. Concerning water quality management and water pollution control. 
Farhan Baehaki, Yasser Wahyudin, Ryzal Perdana, Arlisya Siti Nurfajar \& Zidni Irpan Syaripudin

Rodríguez, I. A., Cárdenas-González, J. F., Juárez, V. M. M., Pérez, A. R., Zarate, M. G. M., and Castillo, N. C. P. (2018). Biosorption of Heavy Metals by Candida albicans. Advances in Bioremediation and Phytoremediation, 43 62. http://dx.doi.org/10.5772/intechopen.72454

Saryono \& Anggraeni, D. M. (2013). Metodologi penelitian kualitatif dan kuantitatif dalam bidang kesehatan. Yogyakarta: Nuha Medika.

Satrianegara, R. (2018, April 6). Citarum dicemari limbah industri 349.000 ton setiap hari. CNBC Indonesia. Retrieved June 11 2020, from https://www.cnbcindonesia.com/news/20180406133932-4-9961/citarum-dicemari-limbah -industri-349000-ton-setiap-hari

Sharov, A. V., Plotnikova, O. M., Evseev, V. V., Rykova, A. I. (2019). Toxicological properties of heavy metals adsorbed on the surface of activated carbon. Periodico Tche Quimica, 16(32), 516-528.

SNI 06-6989.17-2009, Water and waste-part 17: test method for total chromium (Cr-T) with Atomic Absorption Spectrophotometry (AAS)-flame method.

Tumanggor W.R.E., Dharma S., Marsaulina I. (2013). Analisis kandungan pb pada air sumur gali masyarakat di sekitar tempat penimbunan limbah padat industri timah dari daur ulang aki bekas Desa Sei Rotan Kecamatan Sei Tuan Kabupaten Deli Serdang tahun 2012. Lingkungan dan Kesehatan Kerja, 2(1), 1-7. https://jurnal.usu.ac.id/index.php/lkk/article/view/989/600 